\title{
Living and Communicating in a Changing Information Society: The Relevance and Impact of Big Data
}

\author{
Prof. Sabina ADDAMIANO, PhD \\ Department FilCoSpe - Philosophy, Communication, Performing Arts \\ Università degli Studi di Roma Tre, Rome, Italy \\ E-mail: sabina.addamiano@gmail.com
}

\begin{abstract}
The contribution, which has been one of the two keynote speeches to the 2016 PR Trend International Conference, has aimed at pointing out the relevance and impact of Big Data for human communication. The increasing generation of enormous datasets, and with them the so-called datafication of reality, are here seen as the latest evolution of the Information Society which brings with it unprecedented opportunities and questions. They can generate new forms of economic value, but at the same time they strongly impact on fields such as data protection, privacy, social inclusion, quality of life: all issues which are strongly considered in the European vision of the Information Society. In this scenario, Universities can play a major role in contributing to the discussion about the socio-political impact of Big Data, building new skills and competences not only as to data scientists, revising professional profiles working on communication and, last but not least, discuss social, ethical and political implications of the use of Big Data.
\end{abstract}

Keywords: Big Data; Information Society; EU; University teaching and research; Communication-related professional profiles.

Acknowledgements: A special thank to Marco Valerio Principato for the long and passionate discussions about Big Data which have contributed to shape this paper. 


\section{References}

1. Davenport, Th.H. and Patil, D.J. (2012), Data Scientist: The Sexiest Job of the 21st Century, in https://hbr.org/2012/10/data-scientist-the-sexiest-job-of-the-21st-century, last accessed on January 21, 2017.

2. Eisenstein, E.L., L'impatto della stampa sulla società e il pensiero moderni, in Harvey J. Graff (a cura di), Alfabetizzazione e sviluppo sociale in Occidente, Il Mulino 1986, pp. 73-97 (original edition: Id., Some conjectures about the impact of printing on Western society and thought: A preliminary report, pp. 53-68, in Id. (ed.), Literacy and social development in the West: A Reader, Cambridge Studies in Oral and Literate Culture), Cambridge University Press, 1982).

3. European Commission. Building the European Information Society for Us All. First Reflections of the High Level Group of Experts, Interim Report, European CommissionDGV, January 1996, p. 17.

4. MacLuhan, M. (1962), The Gutenberg Galaxy: The Making of Typographic Man, Routledge \& Kegan Paul, London.

5. Mayer-Schönberger, V. and Cukier, K. (2013), Big Data, London, John Murray, p. 6 (Italian edition: Big Data (2013), Milan, Garzanti).

6. Ortoleva, P., Preface to Marvin, C. (1994), Quando le vecchie tecnologie erano nuove. Elettricità e comunicazione a fine Ottocento, Torino, Utet, p. XX (original edition: Marvyn, C. (1988), When Old Technologies Were New: Thinking about Electric Communication in the Late Nineteen Century, Oxford University Press, New York - Oxford.

7. Ong, W. (1982), Orality and Literacy: The Technologizing of the Word, London, Methuen (2nd ed.: 2002, New York, Routledge).

8. Vaidyanatan, S. (2011), The Googlization of Everything (And Why We Should Worry), Berkeley - Los Angeles, University of California Press.

9. archive.ehea.info/getDocument?id=2117, last accessed on January 29, 2017.

10. www.cnet.com/how-to/amazon-alexa-device-compatibility-how-tos-and-muchmore/, last accessed on January 3, 2017.

11. http://ricerca.repubblica.it/repubblica/archivio/repubblica/2016/09/12/comedifendersi-dai-feudatari-digitali29.html, last accessed on January 29, 2017.

12. www.evgenymorozov.com, last accessed on January 29, 2017.

13. http://politiken.dk/udland/art5806849/Danmark-f\%C3\%A5r-som-det-f\%C3\%B8 rste-land-i-verden-en-digital-ambassad\%C3\%B8r, last accessed on January 29,2017]: 
14. http://foreignpolicy.com/2017/01/27/denmark-creates-the-worlds-first-ever-digitalambassador-technology-europe-diplomacy/, last accessed on January 29, 2017.

15. http://eur-lex.europa.eu/legal-content/EN/TXT/PDF/?uri=CELEX:32016R0679\&fro $\mathrm{m}=\mathrm{it}$, last accessed on January 29, 2017.

16. http://publicdomainreview.org/collections/the-telephonoscope-1879/, accessed on January 3, 2017.

17. http://publicdomainreview.org/collections/a-vision-of-isolating-technologyfrom-1906/, accessed on January 3, 2017.

18. http://vantagepartners.it/realta-aumentata, last accessed on January 3, 2017.

19. www.mobileworld.it/2013/02/05/nokia-city-live-si-aggiorna-e-torna-a-chiamarsinokia-city-lens-5022/, last accessed on January 21, 2017.

20. www.smartlook.com/assets/images/dash-1-v2.png, last accessed on January 3, 2017. 